\title{
ABOUT GREBES
}

HANS DE VOGEL, Box 219, Neilburg, Saskatchewan. SOM 2C0

For three days in June there was a Wildlife Technician here to gather eggs of the Red-necked and Eared Grebes. There is a possibility that they pick up toxic material on their wintering grounds on the Pacific and that might be the reason for their poor reproduction. We gathered about a dozen eggs of each species in a short time (one egg out of each nest). For the Rednecked Grebes we had to go to three different lakes. The Eared Grebe eggs we picked up in a matter of hours out of one breeding colony.

The Red-necked Grebe nests are farther apart, not always in bullrushes, but close to shore in the open, built out of material that they bring up from the bottom. The Red-necked Grebes seem to be careless in their breeding habits. As soon as the canoe approaches they leave their nests, dive and surface far out on the lake. Sometimes they cover their eggs, other times they do not even do that. This might be the reason that we found many disturbed Rednecked Grebe's nests.

When approached, the little Eared Grebes leave their nests all at the same time, stay close by and make a sort of complaining muttering sound.

I was going to check on the different nests in early August, instead I spent my time in hospital beds.

Near the house, barn and corrals on our ranch, there is a beautiful, deep, spring-fed, little lake. Through the years it supplied drinking water in the winter for hundreds of cows and calves and dozens of horses. We always had a breeding pair of Red-necked Grebes on that lake. They came early in May, mostly at night. When four or five came at the same time there was a lot of territorial fighting. You could hear their braying call even during the night. When everything was settled a pair of coots nested on one side of the lake, the Red-necked Grebes on the other.

In their mating display, the Rednecked Grebes sometimes stand straight up in the water facing each other. Once I saw one dive, bring up some green moss from the bottom and put it on a floating stick. While doing this they make a soft quacking noise.

The nest is built close to the shore. They keep working at it even during the incubation period. The adults spell off on the nest but I never saw both parents carrying the young. One dives, brings up something and feeds it to the young carried by the other one. What that something is I do not know.

When small the young do not take easily to the water. Once I followed the pairs in the canoe. The one carrying the three small young stayed above the water longer than the other one. When it finally dived, two of the young seemed to want to get in the canoe. When I put the paddle in the water, both crawled onto it. The young are fed until about half grown.

Several mother ducks brought their young to the lake to raise. the young grebes mixed freely with the ducklings. About halfway through September all the grebes were gone from our lake. About that time there were hundreds of grebes on Big Manitou Lake. Maybe that is a staging area before migrating to the Pacific. 